\title{
Climate change and food security: challenges for plant health, plant breeding and genetic resources
}

\author{
Tomasz Oszako1, Justyna A. Nowakowska ${ }^{\square}$ \\ ${ }^{1}$ Białystok University of Technology, Faculty of Forestry in Hajnówka, Piłsudskiego 8, 17-200 Hajnówka, Poland \\ ${ }^{2}$ Forest Research Institute, Laboratory of Molecular Biology, Sękocin Stary, Braci Leśnej 3, 05-090 Raszyn, Poland, \\ phone: +48 227150467, e-mail: J.Nowakowska@ibles.waw.pl
}

On July 14, 2015, in Milan (Italy), an international conference title was held under above as a part of EXPO events. There were several urgent matters discussed amongst European Union (EU) officials (the organisers from DG Sante), representatives of agricultural and horticultural organisations and an international audience. The special focus was put on the

- Impact of climate change, emerging risks and plant disease on food security,

- Emerging risks on plant health: threats and opportunities for the European Union,

- Inspection and control systems at the border,

- Early warning and monitoring systems to fight plant diseases.

The discussion during the Panel debate oscillated about the efficiency of the current legislative systems to protect European natural environments, including forestry. Unfortunately, there are too many examples when the current system failed. However, climate change (CC) threats not only the world's biodiversity but also increases the impacts of pests, which threat agriculture, aquaculture, fisheries and forestry production. By the year 2050, human population in the world will reach 9.5 billion people (population growing rate is $1.14 \%$ per year). The global food production must increase by $50-60 \%$ to meet projected demand of the world's population. In this respect, plant health matters and the international co-operation to control spread of pests is crucial. The International Plant Protection Convention (IPPC) estimates that $10-16 \%$ of global harvest is lost due to plant pests, which costs us 220 billion USD. The increase in the movements of plants and plant products commodities and people can cause plant health problems, for example, the ash dieback phenomenon.

$\mathrm{CC}$ is altering not only the distribution of animal and plant pests and diseases but the full effects are difficult to predict and need to be assessed on a case-bycase basis. Generally, under CC, pests can establish themselves earlier and have greater impacts, for example, the potato leafhopper Empoasca fabae (Baker et al. 2015). CC can benefit individual species, but when pest species are enhanced by warmer temperatures, agricultural productivity may be placed at greater risk. Temperature anomaly influences the arrival date and infestation severity not only the potato leafhopper; E. fabae is a classic new world long-distance migrant and a significant pest in several agricultural crops (e.g. rice production). Average E. fabae arrival date at different states reveals a clear trend along the south-north axis, with earliest arrival closest to the overwintering range. E. fabae arrival has advanced by 10 days over the past 62 years. E. fabae arrived earlier in warmer years in relation to each target state-level temperature anomaly $\left(3.0\right.$ days $/{ }^{\circ} \mathrm{C}$ increase in temperature anoma1y). Increased temperature had a significant and positive effect on the severity of infestation, and arrival date had a marginal negative effect on severity. These relationships suggest that continued warming could advance the time of E. fabae colonisation and increase their impact on affected crops. 
The next menace connected with CC is the reduction of crop's tolerance and resistance to pests and diseases, decrease in soil fertility and reduction of soil capability to control soil-borne pathogens. A reduction of pollinators, beneficial organisms or effectiveness of safe pesticides is also possible. Owing to the natural evolution (selection), the harmful insects, fungi or bacteria are going to be more resistant to pesticides. If we go away from chemicals, we have to replace them by the biological control and individual target treatment. In Europe, CC creates emerging risks to plant health. European Food Safety Authority (EFSA) and European and Mediterranean Plant Protection Organization (EPPO) support plant health legislation in European Union. The Task Force EU Response to increased phytosanitary interceptions (Report 2014) has been requested to elaborate the following:

1. Principles of the EU strategy on response to interceptions of harmful organisms (HO) in consignments form Third Countries (TC). The proposal should identify amongst others

- the method of assessment of the risk associated to interceptions of particular HOs;

- factors, other than the number of interceptions with $\mathrm{HO}$, to take into consideration for assessing the plant health risk;

- the type and extent of measures towards the TC concerned, related to the identified plant health risk;

- a method of establishment and publication of the 'EU alert lists' related to HO interceptions from TC.

2. The Terms of References of the future Commission's Expert Working Group on Response to Emerging Risks from Imports, responsible for regular analysis of the situation and elaboration of proposals for appropriate actions.

International trade of woody plants, especially live plants for horticulture, is recognised as a major pathway of introductions of plant pests, both herbivores and microorganisms, as hitchhikers and contaminants (Migliorini et al. 2015). The systematic examination of future potential threats caused by invasive alien species (IAS) is seen as an essential component of forest stands management. A consensus approach to determine IAS that are likely to arrive and analysis of their impact on native biodiversity in Europe within the next 10 years has been launched as priority theme of many COST Actions programmes, for example:

- COST FP1401 'A global network of nurseries as early warning system against alien tree pests - Global warning' (in years 2014-2018),

- COST FP1406 'Pine pitch canker: strategies for management of Gibberella circinata in greenhouses and forests - PINESTRENGTH' (2014-2018),

- COST TD1209 'Enhancing understanding of invasive alien pathogens - Alien Challenge' (2013-2016).

The researchers involved in those COST Actions are experienced in monitoring the occurrence and impact of IAS. The officials who carry out Pest Risk Assessment (PRA) based on the information generated by researchers who can allow the import and use of seeds for scientific purposes, as well as the use of potentially sensitive data gathered in such plantings, will contribute significantly to the development of an effective network of nurseries as early warning systems against alien tree pests.

A novel way of identifying potentially harmful organisms for regulation is monitoring European trees planted in regions that export plants to Europe. To this aim, the molecular tools are applied in order to detect and identify domestic or new pests (microorganisms, insects) introduced with transported plant material: mainly, seeds and plant-for-plantings in containers with soil. Genetic assessment of organisms present in soil, especially massive next-generation metabarcoding (NGMB) technologies, have been recently used for this purpose and can be very useful in identification of soil-borne pathogens that may affect any seedling production.

Currently, about 150 species of Phytophthora are known, and every year, the number is increasing, enhancing threat to biodiversity and sustainability of forests in Europe. For instance, from 50 to 200 spores (zoospores) can be found in 1 litre of water collected from main European rivers and via this way are transmitted to new woodlands. Another source of infection are plants for plantings, for example, forest nurseries are places where the hybridisation and the formation of interspecific hybrids occur. The significant improvement of rapid and accurate detection methods of pathogens in water, soil and plant tissues is urgently needed.

Very often, the contribution of soil-borne Phytophthora pathogens is underestimated, and the distinguishing of species under a light microscope requires experi- 


\section{DE GRUYTER \\ OPEN}

ence and specific expertise in regard to the morphological differences between Phytophthora species. From the practical point of view, for example, whilst undertaking treatment measures, it is crucial that pathogenic species can be distinguishable from non-pathogenic ones.
It happens that some hybrids of oomycetes fungi, for example, Phytophthora alni are unlikely to be identified or detected by conventional methods based on morphology, as their features appear to be close or identical to those of the parental species.

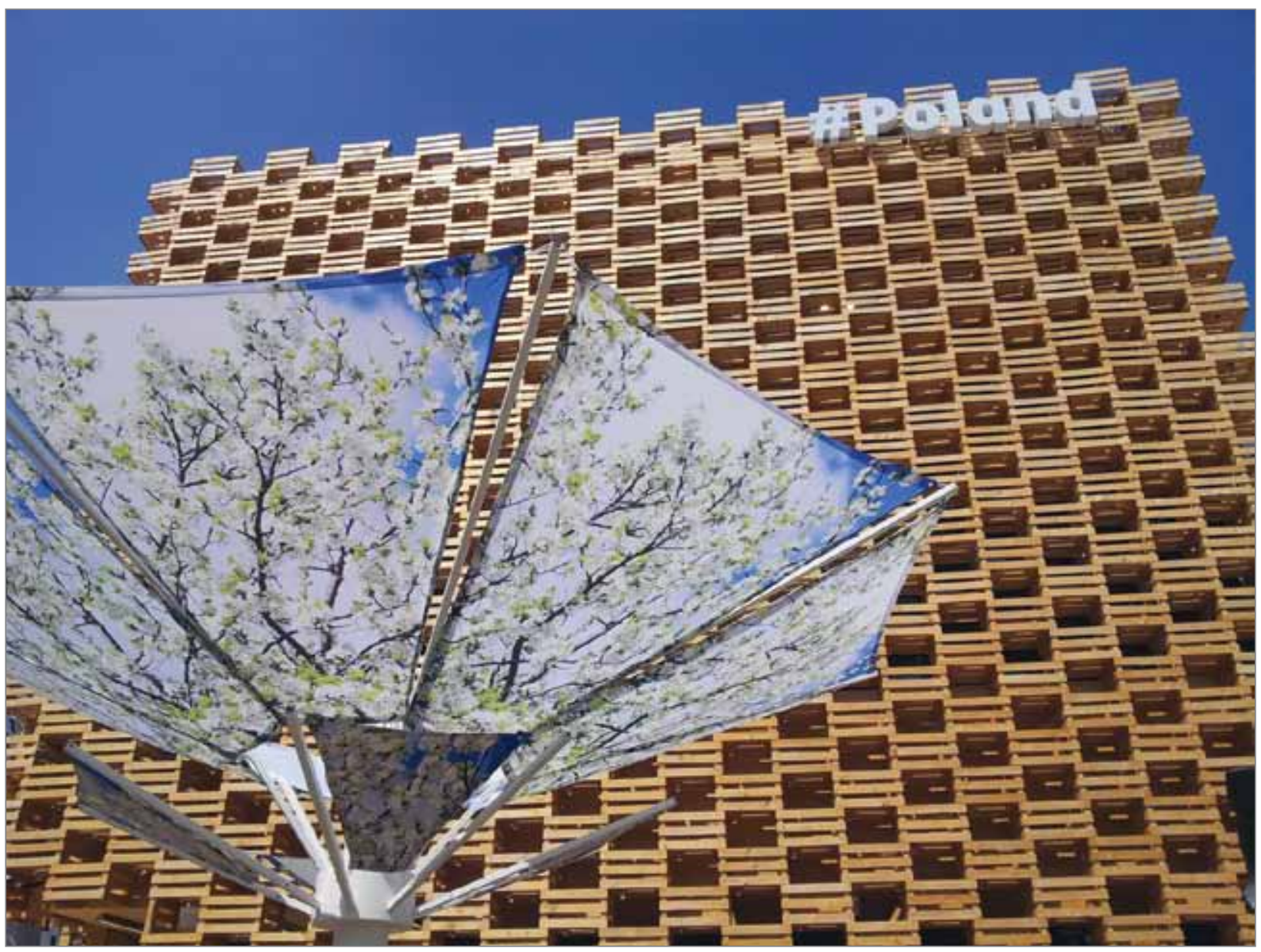

Expo Conference 2015 Centre in Milan (Italy) - for example, Polish stand view. Photo: T. Oszako

The use of the new methods may help forest nurseries to certify their products free of pathogens as well as offer a means by which to attest to the health status of plants at a given time. The classical way of molecular approach in oomycetes' detection rely on seizing the symptomatic tissue in plants or sampling the soil around infected plants, followed by baiting with rhododendron, beech, oak and alder leaves, and then culture of the symptomatic tissues on selective media, DNA extraction from isolates and polymerase chain reaction (PCR) with specific primers (e.g. ITS4/ITS7, or genes such as cox, nad and B-tub). Sometimes, direct analy- sis of DNA based on PCR may help in overcoming the problem through the detection of Phytophthora species in plant tissues at a time when the external symptoms of disease are not yet appeared.

The ultimate comparison of the obtained DNA sequences with data available in international gene banks (accessible on platforms such as www.ncbi.com, www. mycobank.org and http://fungidb.org) leads to the identification of the species in question. Additionally, the real-time PCR method may also help to prove the presence of single oomycete species in the sample. Knowledge about genetic structure (DNA code) of many 
pathogenic strains from single forest tree species will certainly shed the new light on diversity and dynamics of genome evolution, that is, in harmful pathogens from Phytophthora genera damaging European oak stands.

European Horticultural Trade Network (EHTN) was created as a response to the growing flow of international trade (7.8 billion stems of cut flowers in 2014, 2.7 million tons of fruits and vegetables - 250 million pieces). EHTN is a network of the independent national marketing and communications specialists in horticulture industry. The Netherlands is the second larger exporter in the world (first in Europe) that is why developed CLIENT systems to check agricultural products (import/export), now and in the future. In addition Joint Research Center (JRC) created monitoring and early warning system using Copernicus Emergency Management Service (EMS), which provides information about disasters, including meteorological and geophysical hazards. In every 17 days, Landsat covers the earth damages of plants, for example, allowing mapping of massive damaged caused by pine bark beetles or bacterium Xylella fastidiosa in Lecce (Italy) http://emergency.copernicus.eu. $X$. fastidiosa was identified in the past three days in Corsica and the news has already reached French national news.

In conclusion, many of pathogen species are not confined to nurseries and have the potential to invade natural ecosystems. For this reason, the harmonised nursery design, data collection and identification for a range of organisms based on direct observation and symptoms, as well as morphological and molecular techniques will largely contribute to the PRA fulfilment according to the EPPO and IPPC directives.

\section{References}

Baker M.B., Venugopal P.D., Lamp W.O. 2015. Climate Change and Phenology: Empoasca fabae (Hemiptera: Cicadellidae) Migration and Severity of Impact. PLOS ONE, 10 (5), e0124915. doi:10.1371/ journal.pone.0124915
Migliorini D., Ghelardini L., Tondini E., Luchi N., Santini A. 2015. The potential of symptomless potted plants for carrying invasive soilborne plant pathogens. Diversity and Distributions, 21 (10), 1-12.

Report from the $1^{\text {st }}$ meeting of the Task Force EU response to increased phytosanitary interceptions European Commission Health and Consumers Directorate-General, Directorate E - Safety of the food chain E2 - Plant health, Brussels, 10-11 April 2014.

\section{Website about COST Action FP1401}

www.ibles.pl/en/web/cost/

\section{Website about COST Action FP1406}

www.cost.eu/COST_Actions/fps/Actions/FP1406

\section{Websites about $X$. fastidiosa}

http://www.lemonde.fr/biodiversite/article/2015/07/23/ la-bacterie-tueuse-d-oliviers-est-arrivee-en-corse _4694616_1652692.html

http://www.leparisien.fr/societe/xylella-fastidiosa-la -bacterie-tueuse-d-oliviers-reperee-en-corse-22-07 -2015-4964941.php\#xtref=https://www.google. com>http://www.leparisien.fr/societe/xylella-fas tidiosa-la-bacterie-tueuse-d-oliviers-reperee-en -corse-22-07-2015-4964941.php\#xtref=https\%3A \%2F\%2Fwww.google.com

http://www.corsematin.com/article/propriano/bacte rie-xylella-fastidiosa-un-cas-detecte-a-propriano .1876269.html

http://www.corsenetinfos.fr/Xylella-Fastidiosa-Uncas-positif-identifie-en-Corse-du-Sud_a16348. html>http://www.corsenetinfos.fr/Xylella-Fastidio sa-Un-cas-positif-identifie-en-Corse-du-Sud_a16 348.html

Additional related media items are available on the $X y$ lella is currently one of the most active topics in the whole of Medisys pages:

http://medisys.newsbrief.eu/medisys/alertedition/en/ XylellaFastidiosa-PHT.html

http://medisys.newsbrief.eu/medisys/homeedition/en/ home.html 